\title{
PENGARUH MEDIA PEMBELAJARAN DAN MINAT BELAJAR SISWA TERHADAP PENGUASAAN KONSEP ILMU PENGETAHUAN ALAM (EKSPERIMENPADA SMP NEGERI DI KECAMATAN DUREN SAWIT)
}

\author{
Siwi Setyastuti \\ SMPN 27 Jakarta Timur
}

Email :siwi_setyastuti@yahoo.com

\begin{abstract}
ABSTRAK
Tujuan dari penelitian ini adalah untuk mengetahui (1) Pengaruh media pembelajaran terhadap penguasaan konsep IPAsiswa SMPN di Kecamatan Duren Sawit, (2) Pengaruh minat belajar siswa terhadap penguasaan konsep IPAsiswa SMPN di Kecamatan Duren Sawit, (3) Pengaruh interaktif media pembelajaran dan minat belajar siswa terhadap terhadap penguasaan konsep IPA siswa SMPN di Kecamatan Duren Sawit. Metode yang digunakan dalam penelitian ini adalah metode eksperimen. Sampel sebanyak 96 siswa yang berasal dari siswa kelas VII SMPN di Kecamatan Duren Sawit. Pengumpulan data dilaksanakan dengan tes tulis dan angket. Pengujian hipotesis menggunakan ANOVA Dua Arah. Hasil penelitian menunjukkan: (1) Terdapat pengaruh yang signifikan media pembelajaran terhadap penguasaan konsep IPA pada SMP Negeri di Kecamatan Duren Sawit Jakarta Timur yang dibuktikan dengan nilai Sig. 0,000 $<0,05$ dan F hitung = 73,352. (2) Terdapat pengaruh yang signifikan minat belajar terhadap penguasaan konsep IPA pada SMP Negeri di Kecamatan Duren Sawit Jakarta Timur, yang dibuktikan dengan nilai Sig. 0,004 < 0,05 dan F hitung $=8$,980. (3) Terdapat pengaruh interaktif yang tidak signifikan media pembelajaran dan minat belajar siswa terhadap penguasaan konsep IPA pada SMP Negeri di Kecamatan Duren Sawit Jakarta Timur yang dibuktikan dengan nilai Sig. 0,476 > 0,05 dan F hitung = 0,512. Saran dari hasil penelitian ini adalah media pembelajaran Flip Book dapat digunakan guru untuk kegiatan pembelajaran sehari-hari sehingga dapat meningkatkan kompetensi guru.
\end{abstract}

Kata kunci: Media Pembelajaran, Minat Belajar, Penguasaan Konsep PENDAHULUAN

Pendidikan Nasional adalah pendidikan yang berdasarkan Pancasila dan Undang-Undang Dasar Negara Republik Indonesia Tahun 1945 yang berakar pada nilai-nilai agama, kebudayaan nasional Indonesia dan tanggap terhadap tuntutan perubahan zaman. Untuk mengembangkan potensi peserta didik dalam hal berilmu khususnya pelajaran Ilmu Pengetahuan Alam atau IPA yang mengajarkan pengetahuan tentang alam semesta dan gejala-gejalanya yang diperlukan dalam kehidupan sehari-hari. Alam semesta dan gejala alam ini dapat dipahami oleh peserta didik melalui hukum, teori, dan konsep. Gejala alam dan fakta tersebut menjadikan pembelajaran IPA tidak hanya verbal tetapi jugafaktual.

Pada aspek biologi, IPA mengkaji fenomena tentang makhluk hidup. Salah satunya materi Klasifikasi Makhluk Hidup. Materi ini membahas keanekaragaman makhluk hidup dan pengelompokkannya. Banyaknya makhuk hidup yang ada di alam ini membuat siswa tidak mungkin mengenal semuanya. Apalagi siswa yang berada di kota besar seperti Jakarta yang sudah tidak mengenal berbagai macam hewan ataupun tumbuhan karena sudah berkurangnya mahkluk hidup tersebut. Siswa menjadi kurang tertarik dalam mempelajarinya padahal siswa harus memahami konsep pada materi ini. Penguasaan konsep dalam pembelajaran dapat diketahui melalui hasil belajar yang diperoleh peserta didik. Menurut Bloom, secara garis besar hasil belajar terbagi kedalam tiga ranah yakni kognitif, afektif dan psikomotorik. Adapun ranah kognitif menurut Bloom terbagi menjadi 6 jenjang yaitu $\mathrm{C} 1$ mengingat, $\mathrm{C} 2$ memahami, C3 
mengaplikasikan, C4 menganalisis, C5 mengevaluasi dan C6 mencipta (Ella Yulaelawati, 2004:59-60). Oleh karena itu berdasarkan penjelasan tersebut maka penguasaan konsep peserta didik dapat dinilai dengan melihat hasil belajar pada ranah kognitif.Jadi penguasaan konsep materi Klasifikasi Makhluk Hidup yaitu, mengamati makhluk hidup yang satu dengan yang lainnya berdasarkan ciri khusus kehidupan yang dimilikinya, dan mendeskripsikan pentingnya dilakukan klasifikasi makhluk hidup,kemudian membuat perbandingan ciri-ciri khusus tiap kingdom dalam sistem 5 kingdom serta mengklasifikasi beberapa mahluk hidup di sekitar berdasar ciri yang diamati.

Untuk itu maka diperlukan media pembelajaran yang dapat membantu siswa dalam memahami pada materi Klasifikasi Makhluk Hidup tersebut. Media sangat diperlukan dalam penguasaan konsep materi tersebut karena media merupakan pengantar atau perantara pesan kepada siswa. Media berarti sebagai sarana yang berfungsi menyalurkan pengetahuan dariguru kepada siswabaikberupa audio, visual ataupun audio visual. Media pembelajaran adalah segala sesuatu yang dapat menyalurkan pesan, dapat merangsang pikiran, perasaan, dan kemauan peserta didik sehingga dapat mendorong terciptanya proses belajar pada diri peserta didik. Salah satujenis media pembelajaran adalah multimedia yang berarti gabungan dari berbagai media yang terintegrasi.

Penguasaankonsep IPA dipengaruhi oleh faktor internal dan faktor eksternal siswa. Faktor internal adalah faktor yang berasal dari diri siswa sendiri seperti minat, bakat, dan motivasi. Sedangkan faktor eksternal adalah faktor yang berasal dari luar seperti penggunaan media pembelajaran, lingkungan sekolah, cara mengajar guru, dan lain-lain. Faktor internal yaitu minat belajar siswa dan faktor eksternal yaitu media pembelajaran dianggap penulis menjadi faktor yang penting untuk mendukung keberhasilan siswa dalam penguasan konsep IPA.

Berdasarkan latar belakang yang telah diuraikan di atas, maka peneliti tertarik untuk melakukan penelitian yang dituangkan dalam tesis berjudul "Pengaruh Media Pembelajaran dan Minat Belajar Siswa Terhadap Penguasaan Konsep IPA (Eksperimen pada siswa kelas VII di SMPN di Kecamatan Duren Sawit Jakarta Timur).

\section{KAJIAN LITELATUR}

\section{PenguasaanKonsep IPA}

Konsep menurut Sardiman (2010: 85) adalah satuan arti yang mewakili objek yang mempunyai ciri-ciri umum. Konsep menurut Dahar (2002 : 64) merupakan suatu abstraksi mental yang mewakili satu kelas stimulus. Suatu konsep yang telah dipelajari dapat ditampilkan pada perilaku tertentu.

Penguasaan konsep dapat diartikan sebagai kemampuan memahami makna materi, memadukan konsep dan mampu menggunakan atau menerapkan materi yang sudah dipelajari (Usman, 1992: 78). Adapun yang dimaksud dengan penguasaan konsep menurut Daharadalah kemampuan siswa dalam memahami makna secara ilmiah baik teori maupun penerapannya dalam kehidupan sehari-hari. Lebih lanjut, Djamarah (2002:31) mengemukakan dengan penguasaan konsep didapat pengertian atas kata-kata yang dpelajarinya. Dengan penguasaan konsep menurut Winkel dan Anderson dalam Rustaman (2005:29) siswa dapat meningkatkan kemahiran intelektualnya dan membantu dalam memecahkan persoalan yang dihadapinya serta menimbulkan pembelajaran bermakna.

Penguasaan konsep dalam pembelajaran dapat diketahui melalui hasil belajar yang diperoleh peserta didik. Menurut Bloom, secara garis besar hasil belajar terbagi kedalam tiga ranah yakni kognitif, afektif dan psikomotorik. Adapun ranah kognitif menurut Bloom terbagi menjadi 6 jenjang yaitu $\mathrm{C} 1$ mengingat, C2 memahami, C3 mengaplikasikan, C4 menganalisis, C5 mengevaluasi dan C6 mencipta (Ella Yulaelawati, 2004:59-60).

Ilmu Pengetahuan Alam (IPA) didefinisikan sebagai kumpulan pengetahuan yang tersusun secara terbimbing. Oleh karena itu pembelajaran IPA di SMP/MTs menekankan pada 
pemberian pengalaman belajar secara langsung melalui penggunaan dan pengembangan ketrampilan proses dan sikap ilmiah. Pembelajaran IPA menekankan pada pengalaman langsung untuk memahami alam sekitar melalui proses mencari tahu dan berbuat, sehingga memperoleh pemahaman yang lebih mendalam (Virgana, 2014:164).

\section{Media Pembelajaran}

Media berasal dari bahasa latin merupakan bentuk jamak dari "Medium" yang secara harfiah berarti "Perantara" atau "Pengantar" yaitu perantara atau pengantar sumber pesan dengan penerima pesan (Sanjaya, 2010:163). Media merupakan sarana komunikasi dan sumber informasi. Menurut Rohani (1997:3) Media adalah segala sesuatu yang dapat diindra yang berfungsi sebagai perantara/sarana/alat untuk proses komunikasi. Sadiman (2007:6) menyatakan bahwa media adalah perantara atau pengantar pesan dari pengirim ke penerima pesan.Jadi media adalah sarana yang digunakan untuk mengantarkan pesan dari pengirim kepenerima dalam proses komunikasi.

Media pembelajaran merupakan segala bentuk perangsang dan alat yang disediakan guru untuk mendorong siswa belajar secara cepat, tepat, mudah, benar, dan tidak terjadinya verbalisme (Hanafiah dan Suhana, 2012:59). Prinsip yang harus diperhatikan dalam media pembelajaran yaitu media yang digunakan harus sesuai dan diarahkan untuk mencapai tujuan pembelajaran, sesuai dengan materi pembelajaran, sesuai dengan minat, kebutuhan dan kondisi siswa, memperhatikan efektivitas dan efisien, dan harus sesuai dengan kemampuan guru dalam mengoperasikannya (Sanjaya, 2010:173-174). Pengertian multimedia menurut Agus Suheri (2006: 3) adalah media yang menggabungkan dua unsur atau lebih media yang terdiri dari teks, grafis, gambar, foto, audio, video dan animasi secara terintegrasi. Multimedia merupakan kesatuan atau urutan dari berbagai bentuk media yang diberikan pada presentasi atau program pembelajaran mandiri.

\section{MinatBelajar}

Minat adalah kecenderungan dan kegairahan yang tinggi atau keinginan yang besar untuk sesuatu. Dalam hal ini ada dua hal yang harus diperhatikan yaitu ada minat pembawaan dan minat yang muncul karena adanya pengaruh dari luar (Siregar dan Nara, 2014:176).

Menurut Daradjat, dkk (2001:113), pengertian minat belajar merupakan suatu dorongan yang tumbuh dalam diri seseorang untuk mewujudkan sesuatu yang dianggap orang lain berharga. Menurut Djamarah (2002:157) menyebutkan minat belajar cenderung menghasilkan prestasi yang tinggi, sebaliknya minat belajar yang kurang akan menghasilkan prestasi belajar yang rendah.

\section{METODE PENELITIAN}

Metode yang digunakan dalam penelitian ini adalah metode eksperimen, yaitu dengan memberikan jenis perlakuan secara langsung yang berbeda pada dua kelompok belajar siswa.Dalam melakukan penelitian ini penulis menggunakan desain eksperimen randomized control group design dengan rancangan faktorial $2 \times 2$. Variabel media pembelajaran $(A)$ terdiri atas media pembelajaran Pesona Edu $\left(A_{1}\right)$ untuk kelompok kontrol, dan media pembelajaran Flip $\operatorname{Book}\left(A_{2}\right)$ untuk kelompok eksperimen. Variabel atribut minat belajar (B) dibedakan menjadi dua tingkat, yaitu tingkat minat belajar tinggi $\left(B_{1}\right)$ dan tingkat minat belajar rendah $\left(B_{2}\right)$. 
Dalam penelitian yang dilakukan penulis bertujuan untuk menguji perbedaan rata-rata skor dengan 2 variabel bebas, maka pengujian hipotesis penelitian yang digunakan adalah analisis varians (ANAVA) dua arah. Adapun desain penelitiannya dapat dilihat pada tabel berikut:

Tabel 1. Desain Penelitian

\begin{tabular}{|l|l|l|}
\hline \multicolumn{1}{|c|}{$\begin{array}{l}\text { Media } \\
\text { Minat belajar }\end{array}$} & $\begin{array}{l}\text { PesonaEdu } \\
\left(A_{1}\right)\end{array}$ & $\begin{array}{l}\text { FlipBook } \\
\left(A_{2}\right)\end{array}$ \\
\hline Tinggi $\left(B_{1}\right)$ & $A_{1} B_{1}$ & $A_{2} B_{1}$ \\
\hline Rendah $\left(B_{2}\right)$ & $A_{1} B_{2}$ & $A_{2} B_{2}$ \\
\hline
\end{tabular}




\section{HASIL DAN PEMBAHASAN}

\section{Pengaruh Media Pembelajaran terhadap Penguasaan Konsep IPA}

Hasil penelitian menunjukan bahwa kelompok media pembelajaran antara media pembelajaran Pesona Edu dan Flip Book diperoleh nilai Sig. 0,000. Dengan demikian hipotesis pertama teruji kebenarannya nilai Sig $<0,05 ; 0,000<$ 0,05 secara signifikan dapat dan diterima. Sehingga dapat disimpulkan terdapat perbedaan pengaruh yang signifikan penggunaan media pembelajaran Pesona Edu dan media pembelajaran Flip Book terhadap penguasaan konsep IPA. Rata-rata hasil belajar IPA yang belajar dengan media pembelajaran Flip Book lebih baik daripada yang belajar dengan menggunakanmedia pembelajaran Pesona Edu.

Hasil penelitian ini menunjukkan bahwa penggunaan media yang dibuat guru yaitu Flip Book dapat digunakan dalam kegiatan pembelajaran di sekolah, karena gurulah yang dapat memilih media pembelajaran yang sesuai dengan materi, sarana prasarana sekolah serta kebutuhan peserta didik. Sedangkan media Pesona Edu dalam materi Klasifikasi Makhluk Hidup kurang lengkap dari segi materi untuk digunakan, sehingga siswa kurang dapat memahami materi tersebut. Hal ini mungkin karena media Pesona Edu baru menerapkan IPA untuk tingkat SMP yang berisi Fisika, Biologi, dan Kimia, sehingga masih mengembangkan materi untuk versi yang berikutnya. Dengan menggunakan media pembelajaran ternyata juga dapat meningkatkan keingintahuan dan ketertarikan siswa terhadap materi pelajaran yang disampaikan guru. Hal ini didapatkan peneliti pada saat melakukan penelitian ini. Tentunya hal ini sangat baik untuk proses pembelajaran. Dengan ketertarikan ini siswa menjadi antusias dan penguasaan konsepnya semakin baik. Dari hal ini dapatlah disimpulkan bahwa penguasaan konsep IPA salah satunya dipengaruhi oleh penggunaan media pembelajaran yang digunakan oleh guru.

\section{Pengaruh minat belajar terhadap hasil belajar IPA}

Hasil penelitian menunjukan bahwa kelompok belajar IPA antara siswa yang memiliki minat belajar tinggi dan minat belajar rendah diperoleh nilai Sig. 0,004. Dengan demikian Hipotesis Kedua teruji kebenarannya nilai Sig. $<0,05 ; 0,004<0,05$ secara signifikan dapat dan diterima.Sehingga dapat disimpulkan terdapat perbedaan pengaruh yang signifikan antara minat belajar tinggi dan minat belajar rendah terhadap penguasan konsep IPA. Rata-rata hasil belajar IPA yang mempunyai minat belajar tinggi lebih baik daripada yang mempunyai minat belajar rendah.

Fenomena ini menunjukan siswa yang memiliki minat belajar yang tinggi menimbulkan dorongan yang kuat dari dalam diri untuk berkompetensi sehingga membuat siswa lebih percaya diri dalam menjawab soal, belajar lebih senang karena tidak ada unsur paksaan, kesadaran tinggi lebih besar, dan merasa bertanggung jawab. Penguasaan konsep yang dilihat dari hasil belajar adalah seluruh efisiensi dan hasil yang dicapai melalui proses belajar mengajar di sekolah yang dinyatakan dengan angka-angka atau nilai-nilai berdasarkan tes hasil belajar. Dari hal ini dapatlah disimpulkan bahwa penguasaan konsep IPA salah satunya dipengaruhi oleh minat belajar siswa.

\section{Pengaruh Interaktif Media Pembelajaran dan Minat Belajar terhadap Penguasaan Konsep IPA}

Hasil penelitian menunjukan bahwa kelompok penggunaan media pembelajaran antara menggunakan Pesona Edu dan Flip Book serta minat belajar tinggi dan minat belajar rendah diperoleh sig 0,476>0,05; ini berarti tidak terdapat pengaruh interaksi antara media pembelajaran dengan minat belajar siswa.

\section{KESIMPULAN}

1. Terdapat pengaruh yang signifikan media pembelajaran terhadap penguasaan konsep IPA pada SMP Negeri di Kecamatan Duren Sawit Jakarta Timur . Hal tersebut dibuktikan dengan nilai Sig. 0,000 $<0,05$ dan F hitung = 73,352. Dengan demikian terdapat perbedaan pengaruh yang signifikan media pembelajaran terhadap penguasaan konsep IPA siswa.

2. Terdapat pengaruh yang signifikan minat belajar terhadap penguasaan konsep IPA pada SMP Negeri di Kecamatan Duren Sawit Jakarta Timur, hal tersebut dibuktikan dengan Sign 0,004 < 0,05 dan F hitung = 8,980 .. Dengan demikian terdapat perbedaan pengaruh yang sangat signifikan antara minat belajar terhadap penguasaan konsep IPA. 
3. Terdapat pengaruh interaktif yang tidak signifikan media pembelajaran dan minat belajar siswa terhadap penguasaan konsep IPA pada SMP Negeri di Kecamatan Duren Sawit Jakarta Timur. Hal ini dibuktikan dengan nilai sig. 0,476 >0,05 dan F hitung $=0,512$. Dengan demikian dapat disimpulkan bahwa terdapat pengaruh interaktif yang tidak signifikan media pembelajaran dan minat belajar terhadap penguasaan konsep IPA.

\section{DAFTAR PUSTAKA}

U.S Supardi, dkk. 2012. "Pengaruh Media Pembelajaran dan Minat Belajar Siswa Terhadap Hasil Belajar Fisik". Jurnal ilmiah pendidikan MIPA. Vol 2. No. 1: 71-81 (diakses 16 Desember 2015)

Dahar, R. W. 2002. Teori-teori Belajar dan Pembelajaran. Jakarta: Erlangga

Daradjat, Z. 2001. Minat Siswa dalamP embelajaran. Jakarta: PT. Rineka Cipta

Hanifiah, Nanang dan Suhana, Cucu. 2012. Konsep Strategi Pembelajaran. Bandung: Refika Aditama

Rohani, Ahmad. 1997. Media Instruksional Edukatif. Jakarta: Rineke Cipta

Sadiman, Arief S., dkk. 2007. Media Pendidikan. Jakarta: PT. Raja Grafindo Persada

Sanjaya, Wina. 2010. Strategi Pembelajaran Berorientasi Standar Proses Pendidikan. Jakarta: Kencana

Yulaelawati, Ella. 2004. Kurikulum dan Pembelajaran Filosofi Teori dan Aplikasi. Jakarta: Pakar Raya

Siregar, Eveline dan Nara, hartini. 2014. Teori Belajar dan Pembelajaran. Bogor: Ghalia Indonesia

Suheri, Agus. 2006. Animasi Multimedia Pembelajaran. Jurnal Media Teknologi, Vo.2, No.1. Cianjur: UniversitasSuryakencana

Usman, M. Uzer. 2002. Menjadi Guru Profesional. Bandung: Rosda karya

Virgana. 2014. Manajemen Kurikulum MIPA. Tangerang: Pustaka Mandiri. 